\title{
Teachers' Attitude, ICT Facilities Utilization and Teaching Effectiveness of Mathematics Teachers In Public Secondary Schools In Cross River State, Nigeria
}

\author{
Julius U. Ukah \& Samuel Odey \\ Department of Curriculum and Teaching \\ Faculty of Education \\ University of Calabar \\ Calabar, Nigeria \\ E-mail: juliusukah98@gmail.com \\ Phones: +234803-300-9035, +234-708-704-0000
}

\begin{abstract}
Teaching in- effectiveness of most mathematics teachers has been attributed a negative attitude of the teachers and their inability to utilize modern ICT facilities in the teaching of the subject. The study was on the influence of teachers' attitude towards ICT variables, the utilization of ICT facilities and the teaching effectiveness of mathematics teachers in public senior secondary schools in Cross River State. Two hypotheses were drawn from the stated research questions built around the dependent and independent variables. Literature review was carried out according to the variables in the study. A survey design was adopted based on the descriptive nature of the study, while the random sampling technique was used. Two sets of structured questionnaires, titled; 'Teacher Effectiveness Questionnaire' (TEQ) and 'ICT Evaluation Test Questionnaire' (ICTETQ) were designed to obtain data from respondents. Data collected were analysed using the t-test statistic for the first hypothesis and Analysis of Variance (ANOVA) statistic for the last hypothesis. The hypotheses were tested at .05 levels of significance. The results of the findings were as follows: There is no significant influence of mathematics teachers' attitude towards ICT facilities and their teaching effectiveness in public senior secondary schools in Cross River State; facilities utilization has no significant influence on mathematics teachers' effectiveness in public senior secondary schools in Cross River State.Based on the findings, it was recommended among other things that basic training and other facilities like electricity be made available in schools to stimulate a positive attitude in Mathematics teachers and to able them (mathematics teachers), utilize the available ICT facilities and others facilities that should be provided in schools while at the same time teachers' attitude should be channelled in the direction of imbibing and integrating ICTs into teaching so as to ensure an effective mathematics teaching in public senior secondary schools in Cross River State.
\end{abstract}

Keywords: Teachers' attitude, ICT facilities utilization and teaching effectiveness

Aims Research Journal Reference Format:

Julius U. Ukah \& Samuel Odey. (2018): Teachers' Attitude, ICT Facilities Utilization and Teaching Effectiveness of Mathematics Teachers In Public Secondary Schools In Cross River State, Nigeria. Advances in Multidisciplinary \& Scientific Research Journal. Vol. 4. No.1, Pp 83-94

\section{BACKGROUND TO THE STUDY}

ICT integration into the teaching profession is a function of many variables. These variables among other things helps in determining the impact of the integration and the resultant consequences on both teachers and students. The attitude of teachers towards ICT facilities to a great extent have the capacity to charge teachers to employ or not to employ ICT facilities in managing classroom instruction. The utilization of ICT facilities in the management of classroom instruction can be a direct function of teachers' attitude towards these resources. While it is obvious that some teachers may insist on ICT-facilities to boast teaching effectiveness in our secondary schools, others may not see any significant impact between teaching effectiveness in schools.

Teaching effectiveness and its measurement have generated a lot of controversy the world over as there has been no single and acceptable definition of the term owing to divergent views among authors on what effective teaching should be as it has been defined in different ways by researchers. Anderson (1991) stated that "an effective teacher is one who quite consistently achieves goals which either directly or indirectly focus on the learning of their students". It has equally been considered as the degree to which a teacher achieves the desired effects upon students. 
"Effective teachers are those who achieve the goals which they set for themselves or which they have set for them by others (Ministries of Education, Legislators and School administrators). As a consequence, those who study and attempt to improve teacher effectiveness must be cognizant of the goals imposed on teachers or the goals that teachers establish for themselves or both". The effects of this definition is that effective teachers must possess the knowledge, competency and skills needed to attain definite instructional goals, and must be able to use that knowledge, competencies and those skills appropriately if these goals are to be achieved (Onyekuru\&lbegbunam, 2013). Effective teaching is synonymous with teaching (teacher) effectiveness and has been defined in three basic ways These include definitions in terms of ; Teachers' personalities; Teacher-pupil interactions and Teachers' impact on pupil's behaviour. Evan, (2006) posited that the presage, process and product aspects of teaching are well represented in these definitions. The indication and process aspects of teaching bear direct relationship to teachers' personalities and teacher-pupil interactions. Similarly, the product aspect bears direct relationship to teacher impact on pupil's behaviour.

Along teachers' personality line, Afe (2003) defined teaching effectiveness as the type of teaching characterized by the exhibition of intellectual, social and emotional stability, love for children and positive disposition towards the teaching profession and ability to inspire good qualities in students. It was also defined by Evans (2006) as a manifestation of knowledge of content, skills in lesson presentation and creating desirable atmosphere for learning. It has been suggested that teachers' good teaching personalities should be able to translate to impartation of quality knowledge to students. However, critics of this line of definition based on teachers' personal qualities have argued that teachers' personalities may not be sufficient to predict actual increase in students' knowledge. Along teacherpupil interaction line, he also defined teaching effectiveness as a kind of classroom transactions that occur between teachers and students resulting to increase in students' knowledge. This refers to communication skills, use of praises, rewards, motivation, e.t.c during teaching process. This has also been criticized for blurred distinction between it and definitions based on teachers' personalities. Along the line of teachers' impact on pupils' behaviour, Akpan (1996) representing a pragmatic point of view, defined teaching effectiveness as the achievement of all or most of the learning objectives and reduction of differences in cognitive levels among the students. Evans (2006) defined it as the degree to which specific instructional objectives are achieved by the students under the guidance of a given teacher or teachers. This definition is based on the understanding that the desired products of teaching effort include measured achievement gains, growth in intellectual skills, aptitude and improvement in attitude towards learning. In the paper, teaching effectiveness is operationalized with Knowledge of the subject matter (KSM), Ability to motivate students(AMS), Communication Skills (CS), Inter-personal relationship (IPR) and evaluation techniques (ET)

\section{REVIEW OF RELATED LITERATURE}

Albirini, (2004) carried out study on the factors associated with the attitude of high school teachers in Syria towards ICT facilities and reported that the confidence level of ICT integration in the teaching and learning environment can still be guaranteed, notwithstanding teachers' attitude towards ICT facilities. The writer insisted that teachers' attitude does not influence teaching effectiveness. The above assertions were equally collaborated by (Harrison \& Rainer, 1992) also maintained in their study on the examination of the factors, structures and concurrent validates for the computer attitude scale, the computer anxiety rating scale and computer self-efficacy scale study involving 150 teachers with as high $80 \%$ positive rating scale. They reported that ICT integration is inhibited by a number of other factors outside attitude, and these may include their (teachers') inability to use computers and internet in the teaching process.

In addition, teachers were noted to be having limited knowledge and technical skills to effectively deploy new hardware and software in their teaching, couple with the inadequacy in infrastructure availability. The concern here is perceived ignorance from stake holders of the benefits ICT offers in the teaching and learning situation. Mselle, (2012) in his study on the use of ICT in Tanzania reported above and opined that a positive attitude towards ICT usage was still at the infancy state, particularly in most of the developing countries including Nigeria.

Furthermore, Hare (2007) added that most countries are still at the stage of formulating policies to be implemented in their school systems. In most secondary schools, students are still being taught what was taught in the 1950 s and in the same ways because of the in negative attitude towards the use of ICT as pedagogical facility. In the words of (Wild, M.,1996) even though there is a dramatic impact and growth of ICT in the society, many classroom, staff rooms in schools and colleges still look alike and operate in a remarkably similar way to those of two to three decades ago. Condie and Livingstone (2007) found in their study on 'Blending Online learning with traditional approaches' that, some teachers continued to display negative attitude towards ICT and this usually negative impact on their examination results and teaching effectiveness. 
On the contrary however, a Singaporean study by Teo (2006) on the ICT mediated lesson and students computer attitude, several barriers were discovered to be associated with the successful integration of ICT facilities in the teaching and learning situation and some of these problems was the attitude of teachers towards ICTs, inadequate appointment of technical support staff, inadequate appointment and training of student ICT helpers, lack of sufficient time for teachers to prepare for ICT-mediated lessons, insufficient collaboration among teachers preparing for ICTmediated instructions, etc. The study concluded that there was a general poor implementation strategy being exhibited by secondary school teachers towards the development of ICTs pedagogical experiments.

Corroborating, Wyarusy, (2006) discovered that lack of financial resources and attitude were the major obstacles, facing most secondary schools teachers towards embracing ICT facilities and that attitude problem has catalytic effect on other variables; lack of internet connectivity, unsatisfactory teachers' remuneration, couple with power fluctuation, uncompleted and the use of old syllabi. Furthermore, Ndibalema (2014) carried out a study on teachers' attitude towards the use of ICT as pedagogical tools in secondary schools involving 80 teachers randomly sampled from 10 schools a structured questionnaire and interview methods for data collection. The study affirmed that teachers have always demonstrated positive attitude towards ICT as a pedagogical tool. The researcher discovered that most teachers were not using ICT to affect their teaching effectiveness in the affirmative due to other unfamiliarity with the effective use of the facilities. Additionally, Naser, Leong and Fong, (2010) used a survey method to investigate 460 teachers' attitude to ICT utilization in teaching and learning. The findings revealed a low attitude rating of teachers towards ICT use in pedagogical purposes and has played down their teaching effectiveness, though with a significantly positive attitude in general ICT use.

Similarly, Okorie and Agah (2014) in investigating the attitude of teachers towards ICT usage for pedagogical purposes discovered that most teachers showed negative attitude towards ICT usage in the teaching of Chemistry concepts even as specifically recommended in the curriculum. This according to the authors was due to lack of computer and other ICT facilities in the schools and teachers' lack of skills needed for the use of the facilities. In an effort to profess a solution to the above problem, the informal experimental design was used to compare the mean attitude scores of teachers before and after their exposure to ICTs in the teaching of Chemistry and the mean attitude scores of urban and rural teachers before and after the exposure to use of computers in the teaching of Chemistry.

The result showed that there was a 42.14 mean attitude score before exposure, indicating a negative attitude towards the use of ICT software to teach chemistry. The after exposures mean attitude score was 73.29, indicating that the after exposure exercise has the capacity to change or enhance chemistry attitude to the use of computers instructional software package in chemical bonding. The study emphasized the need for teachers to be exposed, trained and educated on the importance of ICTS in education; it calls for the need for teachers to be given access to the facilities as this will likely influence their general attitude and perception towards ICT usage. The fear of failure on the part of the teachers may have induced their negative attitude.

For Cuban (1986); Tyack and Cuban (1995), the failure of ICT applications in most pedagogical concern may be due to teachers' inadequate preparation and lack of adequate support systems towards to the use of the technology. Negative attitude from teachers retards progress in the implementation of ICT policies. This could be one reason why most teachers do not see the need towards implementing ICTs in the teaching of mathematics in secondary schools as necessary. Corroborating on the affirmation of teachers' attitude role on teaching effectiveness, Ugwu (2011) attributed teachers' negative attitude to fear and anxiety over job insecurity and displacement that are erroneously associated with ICTs and that this always result in ineffectiveness. His views were collaborated with those of Olubiyo and Sheyi (2011), who considered teachers with such fears and anxiety as illiterates in terms of ICT use-ability, and even when such facilities are available, they are adequately and effectively exploited.

\subsection{ICT facilities Utilization and teachers' teaching effectiveness}

Using a descriptive survey in his study carried out in Yobe State, , Apagu (2008) observed that ICT facilities were lacking in technical colleges because of challenges like inadequate power supply, inadequate ICT literate teachers and lack of ICT facilities. With a mean variance of 3.13 and 2.5 for ICT availability and utilization, it was evident that teachers were not exposed to the use of ICT facilities in the classroom, even when most of these facilities are available and accessible. Effective utilization of ICT in teaching therefore depends on teachers' attitude towards the facilities, ICT facilities availability and teachers' competencies in the utilization of these facilities. Ajayi (2008) affirmed that where there are no functional ICT facilities in schools and colleges, inadequate power supply and very low level of ICT literacy among teachers teaching effectiveness would be hampered. Eraut, 1995; Dawes, Mercer \&Wegerit (2000) further posited that teachers need to teach students on how to interact with each other when using the computer collaboratively so that effective and meaningful learning can take place. Effective use of ICT facilities with students in their separate studies can influence teachers' output and which will later manifest in the development of students' thinking and understanding across the curriculum span. 
McClain and Cobb, (2001) mentioned six areas of ICT integration with possible positive outcomes including Mathematics as individual reasoning, their higher-order thinking will improve in the subject. Kirwood, (2000) beliefs in conception change in science with ICT. The low rate ICT utilization in Nigeria in Nigeria secondary schools is attributed to several factors. Adomi and Kpangban, (2010) used a population of 176 respondents in their study on ICT facilities application and utilization in secondary schools revealed that there are poor facilities utilization across schools in Nigeria due to poor information infrastructure. Southehwood (2004) reported that more than $40 \%$ of Africa population are in areas not covered by telecomm services. Schools located in such areas will surely experience ICT connectivity problems and utilization.

In a related study, Asiabaka, (2010) accessed the utilization of Information and Communication Technology (ICT) for administrative purposes by principals of government secondary schools in Nigeria, the result showed that for the utilization of broadcast/audio-visual technology for administrative purposes, $69.23 \%$ of principals asserted that projectors were never use in their schools for administrative purposes. $18.46 \%$ used it rarely, $12.3 \%$ used it sometimes, while no principal indicated that they use it always in their schools. In investigating the access to ICT facilities by academic staff and the impact on students' acquisition of basic leaning skills, Akuegwu, Ntukidemand Jaja (2011) noted that knowledge of ICT facilities can influence the extent to their contribution to students' learning and can also impact on students' acquisition of basic employable skills.

The utilization of ICT facilities most time s is hampered by teachers' knowledge of ICT and the availability of these facilities. Kaku (2005) observed in his study of internet use by secondary teachers that the number of computers in most schools laboratory were not enough and that in some cases, only one computer was connected to the internet. The findings showed that the utilization of ICT facilities in secondary schools is a necessary condition for the general effectiveness of the educational system, particularly in this era of globalization. He concluded that the extent of ICT facilities utilization is very low couple with the fact most teachers lack even the knowledge to operate these facilities.

Reporting further on ICT facilities utilization, Kaku (2005) submitted that $71.54 \%$ of principals indicated that televisions and digital cameras are never used in their schools, $24.62 \%$ noted that they were used rarely $4.1 \%$ stated that they were always used, $59.23 \% \mathrm{~s}$ indicated that they were never used. $21.54 \%$ used them rarely, $19.23 \%$, used them sometimes, one of the principals used them always. They result of their findings further revealed that $61.54 \%$ never used radio programmes for educational purposes, $11.54 \%$ used it rarely, $19.23 \%$ used it sometimes, while $7.7 \%$ used it rarely, $3.2 \%$ used sometimes while none of the principals used it always. Results showed that $75.83 \%$ never used the cinema, 14.17 used it rarely and $10 \%$ used it sometimes while $3.33 \%$ used it always. The result further adds that the minority of the principals never used broadcast/audio-visual technology for administrative duties.

\subsection{Statement of the problem}

Secondary schools in Nigeria are faced with challenges, ranging from lack of adequate funding to the overdependent on traditional teaching materials like textbooks and chalkboard in instruction delivery in almost all disciplines including mathematics and this is in most predominant in publicly owned schools. The need therefore to introducemodern technological facilities into teaching to make teachers more effective in their profession has become paramount . The challenging scenario is; what is the attitude of teachers towards this new technology and whether or not they possess the needed knowledge to utilize them in the teaching of mathematics. The researcher is therefore concerned in examining how teachers' attitude towards ICT facilities can influence and their ability to utilize ICT facilities in teaching mathematics influence their teaching effectiveness.

\subsection{Purpose of the study}

The main purpose of this study is to establish the influence of ICT-related variables on teaching effectiveness of mathematics teachers in public secondary schools in Cross River State. Specifically, the study seeks to determine:

i. The influence of mathematics teachers' attitude towards ICT facilities on their teaching effectiveness in public secondary schools

ii. The influence of ICT facilities utilization on the teaching effectiveness of mathematics teachers in public secondary schools

\subsection{Statement of hypotheses}

The following hypotheses are tested in the study:

$\mathrm{H}_{01}$ : Teachers' attitude towards ICT facilities does not significantly influence their teaching effectiveness in senior secondary school mathematics

$\mathrm{H}_{02}$ : There is no significant influence of teachers' ICT facilities utilization on teachers' teaching effectiveness in senior secondary schools mathematics 


\section{METHODOLOGY}

The survey inferential research design was adopted for this study. The research area is Cross River State, Nigeria. The population of the study consist of 375 public senior secondary school mathematics teachers in the state. A census of mathematics teachers in public senior secondary schools in Cross River State. All the mathematics teachers (both professionals and non-professionals) in the sampled schools were used for the study. In addition, each of the 375 mathematics teachers involved in the study were further evaluated by four students on their teaching effectiveness. This was to make the assessments by students even and objective enough rather than limiting it to a student or two. There were altogether 1,500 students used to assess the teachers at the end.

In selecting the students for the study, the random sampling technique was used. The students were made to pick between 'Yes' or 'No' from the folded papers rapped inside a container by the researcher and his team. The sample consisted 375 teachers and 1,500 students from the public senior secondary schools in Cross River State. Two instrumentation were used for study. The first questionnaire titled "ICT Evaluative Test Questionnaire" (ICTETQ) was administered to teachers to evaluate their general attitude towards ICT facilities as well as their abilities to utilize ICT facilities in teaching mathematics in senior secondary schools. The second instrument titled "Teaching Effectiveness Questionnaire" (TEQ) was administered to students to assess their teachers' teaching effectiveness in mathematics. Students on their part were guided by the researchers on how to answer to the questionnaire items. Both instruments were developed by the researchers and validated by three research experts in Measurement and Evaluation. The reliabilities were determined by administrating the instruments to the same instruments 50 teachers and 200 students in selected private secondary schools in Cross River State who were not part of the study. The reliability coefficient value obtained through a test-retest method was 0.70 and above.

\section{RESULTS}

Hypothesis 1: Teachers' attitude towards ICT facilities does not significantly influence teaching effectiveness in Mathematics.

The independent variable in this hypothesis is teachers' attitude towards ICT facilities, and the dependent variable is teaching effectiveness. The independent variable in this hypothesis is teachers' attitude towards ICT facilities and was categorized into negative \& positive attitudes. While the dependent variable is teachers' teaching effectiveness. The independent variable was measured continuously and was coded into discrete data using the 'Transform' icon of the SPSS programme. In determining whether a respondent had negative or positive attitude towards ICT facilities usage, the range of scores was used. The minimum score was 10 points while the maximum score was 32 points giving a range of 22 points. When divided into two the result was 11. Based on this, scorers from 10 points to 21 points were coded as having negative attitude towards ICT facilities usage, while scorers from 22 points to 32 points were coded as having positive attitude towards ICT usage. Since the categories were two, the Independent t-test statistic was employed in testing the hypothesis. Results of the analysis are presented in Table 1

TABLE 1: Summary of independent t-test analysis for the difference in teaching effectiveness between teachers with negative attitude and those with positive attitude.

\begin{tabular}{|l|l|l|l|l|l|l|}
\hline S/No & Teachers' teaching effectiveness & Category & $\mathrm{N}$ & $\mathrm{X}$ & $\mathrm{SD}$ & $\mathrm{t}$ \\
\hline 1 & KSM & Negative & 148 & 21.41 & 3.67 & .160 \\
& & Positive & 227 & 21.48 & 3.82 & \\
\hline 2 & AMS & Negative & 148 & 19.64 & 3.70 & $2.097^{*}$ \\
& & Positive & 227 & 18.88 & 3.25 & \\
\hline 3 & CS & Negative & 148 & 22.39 & 3.40 & $2.169^{*}$ \\
& & Positive & 227 & 21.69 & 2.81 & \\
\hline 4 & IPR & Negative & 148 & 21.49 & 2.83 & .476 \\
& & Positive & 227 & 21.34 & 2.99 & \\
\hline 5 & ET & Negative & 148 & 22.28 & 3.43 & .169 \\
& & Positive & 227 & 22.60 & 3.50 & \\
\hline 6 & Overall teaching effectiveness & Negative & 148 & 107.21 & 12.47 & 1.246 \\
& & Positive & 227 & 105.65 & 11.39 & \\
\hline
\end{tabular}

$\mathrm{P}<.05 ; \mathrm{df}=373 ;$ critical $\mathrm{t}=1.96$ 
At most levels of teaching effectiveness apart from teachers' ability to motivate students and their communication skills, the critical t value of 1.96 was found to be greater that the tabulated values, indicating the negative influence between teachers' attitude towards ICT facilities and teaching effectiveness in mathematics in public senior secondary schools in Cross River State. The null hypothesis was there retained and the alternate rejected.

Hypothesis 2: There is no significant influence of teachers' ICT facilities utilization on teaching effectiveness in secondary schools mathematics.

The independent variable in the hypothesis is ICT facilities utilization and the dependent variable is teaching effectiveness which had five sub variables and the Teachers that scored above the mean were classified as high in teachers' ICT facilities utilization, those that scored within the mean were classified as average in teachers' ICT facilities utilization and those that score below the mean were classified as low in teachers' ICT facilities utilization. Based on this classification, 159 teachers were classified as low in their ICT facilities utilization, 16 teachers was classified as average in their ICT facilities utilization and 200 teachers were classified as high in their ICT facilities utilization. The means and standard deviation of these categories for their teaching effectiveness indices were first computed and compared using the One-Way Analysis of Variance (ANOVA). Thus, the hypothesis was tested on each of the five sub-variables of knowledge of subject matter, ability to motivate students, communication skills, teaching method, and method of evaluation. The group size, mean and standard deviations are shown in Table 2, while the actual result of ANOVA is shown in Table 3.

TABLE 2: Summary of the descriptive statistics of influence of teachers' ICT facilities utilization on teachers' effectiveness

\begin{tabular}{|c|c|c|c|c|}
\hline Teaching effectiveness & $\begin{array}{lr}\text { Influence } & \text { of } \\
\text { teachers' } & \text { ICT } \\
\text { facilities } & \\
\text { utilization } & \\
\end{array}$ & $\mathrm{N}$ & Mean & SD \\
\hline Knowledge of subject matter & $\begin{array}{l}\text { Low } \\
\text { Average } \\
\text { High } \\
\text { Total }\end{array}$ & $\begin{array}{l}159 \\
16 \\
200 \\
375\end{array}$ & $\begin{array}{l}19.03 \\
19.21 \\
18.89 \\
18.96\end{array}$ & $\begin{array}{l}3.32 \\
2.65 \\
3.21 \\
3.23\end{array}$ \\
\hline Ability to motivate students & $\begin{array}{l}\text { Low } \\
\text { Average } \\
\text { High } \\
\text { Total }\end{array}$ & $\begin{array}{l}159 \\
16 \\
200 \\
375\end{array}$ & $\begin{array}{l}19.21 \\
19.56 \\
19.34 \\
19.29 \\
\end{array}$ & $\begin{array}{l}3.12 \\
3.54 \\
3.30 \\
3.23 \\
\end{array}$ \\
\hline Communication skills & $\begin{array}{l}\text { Low } \\
\text { Average } \\
\text { High } \\
\text { Total }\end{array}$ & $\begin{array}{l}159 \\
16 \\
200 \\
375\end{array}$ & $\begin{array}{l}19.05 \\
19.22 \\
18.90 \\
18.97 \\
\end{array}$ & $\begin{array}{l}3.33 \\
2.65 \\
3.19 \\
3.22 \\
\end{array}$ \\
\hline Inter-personal Relations & $\begin{array}{l}\text { Low } \\
\text { Average } \\
\text { High } \\
\text { Total } \\
\end{array}$ & $\begin{array}{l}159 \\
16 \\
200 \\
375 \\
\end{array}$ & $\begin{array}{l}19.03 \\
19.22 \\
18.95 \\
18.99 \\
\end{array}$ & $\begin{array}{l}3.32 \\
2.65 \\
3.24 \\
3.24 \\
\end{array}$ \\
\hline Method of evaluation & $\begin{array}{l}\text { Low } \\
\text { Average } \\
\text { High } \\
\text { Total }\end{array}$ & $\begin{array}{l}159 \\
16 \\
200 \\
375 \\
\end{array}$ & $\begin{array}{l}19.03 \\
19.22 \\
18.88 \\
18.96 \\
\end{array}$ & $\begin{array}{l}3.31 \\
2.65 \\
3.22 \\
3.23 \\
\end{array}$ \\
\hline Overall teaching effectiveness & $\begin{array}{l}\text { Low } \\
\text { Average } \\
\text { High } \\
\text { Total } \\
\end{array}$ & $\begin{array}{l}159 \\
16 \\
200 \\
375 \\
\end{array}$ & $\begin{array}{l}96.04 \\
97.06 \\
95.24 \\
95.66 \\
\end{array}$ & $\begin{array}{l}16.65 \\
11.99 \\
12.97 \\
14.58 \\
\end{array}$ \\
\hline
\end{tabular}


The result of the analysis showed the summary of the descriptive statistics of the influence of teachers' ICT facilities utilization on teacher's effectiveness. The result revealed that teachers who were average in their ICT facilities utilization had the highest mean teacher's effectiveness in terms of knowledge of subject matter $(\bar{X}=19.22)$, followed by teachers who were low in their ICT facilities utilization $(\bar{x}=19.03)$ and lastly by teachers who were high in their ICT facilities utilization $(\bar{X}=18.89)$.

When teacher's effectiveness in terms of ability to motivate students was considered, teachers who were average in their ICT facilities utilization had the highest mean teachers effectiveness in terms of ability to motivate students $(\bar{X}=19.56)$, followed by teachers who were high in their ICT facilities utilization $(\bar{X}=19.34)$ and lastly by teachers who were low in their ICT facilities utilization $(\bar{X}=19.21)$.

When teacher's effectiveness in terms of communication skills was considered, teachers who were average in their ICT facilities utilization had the highest mean of teacher effectiveness in terms of communication skills $(\bar{X}=19.22)$, followed by teachers who were low in their ICT facilities utilization $(\bar{X}=19.05)$ and lastly by teachers who were high in their ICT facilities utilization $(\bar{X}=18.90)$.

When teacher's effectiveness in terms of teaching method was considered, teachers who were average in their ICT facilities utilization had the highest mean teachers effectiveness $(\bar{X}=19.22)$, followed by teachers who were low in their ICT facilities utilization $(\bar{X}=19.03)$ and lastly by teachers who high in their ICT facilities utilization $(\bar{X}=18.95)$. When teacher's effectiveness in terms of method of evaluation was considered, teachers who were average in their ICT facilities utilization had the highest mean teachers effectiveness in terms of method of evaluation $(\bar{X}=19.22)$, followed by teachers who were low in their ICT facilities utilization $(\bar{X}=19.03)$ and lastly by teachers who were high in their ICT facilities utilization $(\bar{X}=18.89)$.

When the overall teacher's effectiveness was considered, teachers who were average in the ICT facilities utilization had the highest mean overall teachers effectiveness $(\bar{X}=97.06)$, followed by teachers who were low in their ICT facilities utilization $(\bar{X}=96.04)$ and lastly by teachers who were high in their ICT facilities utilization $(\bar{X}=95.24)$. To test this hypothesis a One-Way Analysis of Variance was used. The result of the analysis is presented in Table 14. The result of the analysis showed that there is no significant influence of ICT facilities utilization on teachers effectiveness in terms of knowledge of subject matter ( $F=.136 ; p>.05)$; ability to motivate students $(F=.132 ; p>.05)$; communication skills $(F=.150 ; p>.05)$; teaching method $(F=.072 ; p>.05)$; method of evaluation $(F=.137 ; p>.05)$; and overall teacher effectiveness $(F=.213 ; p>.05)$. The null hypothesis was retained. This is because the calculated F-ratios of .136, .132, $.150, .072, .137$ and .213 were found to be less than the critical F. ratio of 3.02 given .05 levels of significance and with 2 and 372 degrees of freedom. This finding implies that teachers' ICT facilities utilization does not significantly influence teachers effectiveness in terms of knowledge of subject matter, ability to motivate students, communication skills, teaching method, method of evaluation and overall teachers effectiveness. 
TABLE 3: Analysis of variance of influence of teachers ICT facilities utilization on teachers' effectiveness

\begin{tabular}{|c|c|c|c|c|c|c|}
\hline $\begin{array}{l}\text { Teaching } \\
\text { effectiveness }\end{array}$ & Source of variation & Sum of squares & $\overline{\mathrm{Dff}}$ & $\begin{array}{l}\text { Mean } \\
\text { square }\end{array}$ & F-value & Sig \\
\hline KSM & $\begin{array}{l}\text { Between Groups } \\
\text { Within Groups } \\
\text { Total }\end{array}$ & $\begin{array}{l}2.857 \\
3898.907 \\
3901.764\end{array}$ & $\begin{array}{l}2 \\
372 \\
374\end{array}$ & $\begin{array}{l}1.428 \\
10.481\end{array}$ & .136 & .873 \\
\hline AMS & $\begin{array}{l}\text { Between Groups } \\
\text { Within Groups } \\
\text { Total }\end{array}$ & $\begin{array}{l}2.765 \\
3888.968 \\
3891.733\end{array}$ & $\begin{array}{l}2 \\
372 \\
374\end{array}$ & $\begin{array}{l}1.382 \\
10.545\end{array}$ & .132 & .876 \\
\hline CS & $\begin{array}{l}\text { Between Groups } \\
\text { Within Groups } \\
\text { Total }\end{array}$ & $\begin{array}{l}3.132 \\
3878.877 \\
3882.009\end{array}$ & $\begin{array}{l}2 \\
372 \\
374\end{array}$ & $\begin{array}{l}1.566 \\
10.427\end{array}$ & .150 & .861 \\
\hline IPR & $\begin{array}{l}\text { Between Groups } \\
\text { Within Groups } \\
\text { Total }\end{array}$ & $\begin{array}{l}1.511 \\
3928.222 \\
3929.733\end{array}$ & $\begin{array}{l}2 \\
372 \\
374\end{array}$ & $\begin{array}{l}.756 \\
10.560\end{array}$ & .072 & .931 \\
\hline MOE & $\begin{array}{l}\text { Between Groups } \\
\text { Within Groups } \\
\text { Total }\end{array}$ & $\begin{array}{l}2.864 \\
3900.326 \\
3903.189\end{array}$ & $\begin{array}{l}2 \\
372 \\
374\end{array}$ & $\begin{array}{l}1.432 \\
10.485\end{array}$ & .137 & .872 \\
\hline OTE & $\begin{array}{l}\text { Between Groups } \\
\text { Within Groups } \\
\text { Total }\end{array}$ & $\begin{array}{l}91.040 \\
79457.584 \\
79548.624\end{array}$ & $\begin{array}{l}2 \\
372 \\
374\end{array}$ & $\begin{array}{l}45.520 \\
213.596\end{array}$ & .213 & .808 \\
\hline
\end{tabular}

Significant at .05 level; critical $F=3.17 ; \mathrm{df}=2.372$

Where: $\mathrm{KSM}=$ Knowledge of the subject matter, $\mathrm{AMS}=$ Ability to motivate students, $\mathrm{CS}=\mathrm{Communication}$ skills, IPR= Inter-personal relations, $\mathrm{MOE}=$ Method of evaluation and $\mathrm{OTE}=$ Overall teaching effectiveness

\section{DISCUSSION}

\section{Hypothesis 1}

Teachers' attitude towards ICT facilities and teaching effectiveness in mathematics.

The hypothesis was stated in a null form thus; teachers' attitude towards ICT facilities does not significantly influence their teaching effectiveness in public secondary schools mathematic in Cross River State. The null hypothesis was retained and the alternate rejected. Mathematics teachers in this case did not possess positive attitude towards ICT facilities significant enough to influence their teaching effectiveness of mathematics. This is because outside attitude, teachers still feel they are other motivating and significant factors such as ICT knowledge level, teachers' condition of service, working incentives and other teacher-related variables that could significantly influence their teaching effectiveness level.

Conforming the position of the findings of this hypothesis is the view ofNdibalema (2014) who asserted that despite the positive attitude exhibited by teachers towards ICT facilities, there was a non-application of these facilities by teachers for effective teaching and learning due to lack of technological know-how and skills on the part of the teachers. Furthermore, the result equally aligns itself with the view of Wyanisy (2006), who asserted that lack of financial resources was the most serious obstacle inhibiting effective use of ICT facilities by teachers and not attitude. The author posited that teachers may have a positive attitude towards ICT facilities, but that this can be watered down by the lack of internet connectivity, unsatisfactory teachers' remuneration, power fluctuation, uncompleted and the use of old syllabi and that these are more fundamental issues than teachers' attitude.

Again, the finding of the study aligns with the position of Teo (2006), who reported that teachers' attitude towards ICT facilities was inadequate to justify the level of teacher's teaching effectiveness. The author added that other fundamental variables like lack of appointment of technical support staff, inadequate training ICT helpers, insufficient collaboration among teachers preparing for ICT -mediated instructions were more incline to influence teaching effectiveness in any science- oriented teaching. He sees poor implementation strategy exhibited by secondary school teachers towards the development of ICT pedagogical experiments due largely to negative attitude 
The findings of this study also corroborated with the opinion of Harrison and Rainer (1992), who noted that even when positive attitude by teachers induces effectiveness, other teething problems like lack of technical skills and technical competence by teachers to use the facilities may become a hindrance. The findings also agree with the views of Albirini (2004), who affirmed that confidence level of ICT integration can still be guaranteed notwithstanding teachers' attitude.

On the contrary, the result of the study does not conform with Ugwu (2011), who affirmed that negative attitude by teachers towards ICT facilities could retard their progress both in pedagogical purposes and in the actual teachers' implementation of policies in any educational programme. The result is also a departure from the views of Eugene and Agah (2014) whose study posited that teachers' attitude towards ICT facilities can influence their teaching effectiveness in Chemistry as evidence in the mean before teacher exposure to ICT facilities of 42.14 and the mean after exposure 73.29

Additionally, this finding is not in support of Hamson and Paints (1992) views, who suggested that participants with negative attitude towards new technology (ICT) were associated with fewer skills in computer usage and programming. The finding of the study is not also in conformity with the views of Naser, Leong and Fong (2010) who linked teachers' low attitude towards ICT facilities and integration into teaching to their less effectiveness in handling pedagogical concerns, and suggested that, teachers must be trained and retrained on how to handle various ICT facilities for general educational concerns. The authors' opinion advocated a general positive attitude of teachers' towards ICT, outside pedagogical endeavours. The findings of this study also agree with the views of Condie and Livingstone (2007) that teachers' ineffectiveness in the classroom is due largely to their negative attitude towards ICT resources. Considering the above reviews, a greater number of scholars have posited that attitude of mathematics teachers towards ICT facilities may not sufficiently influence their teaching effectiveness. This is because there are other fundamental variables such as technical support services with the needed skills and adequate power supply systems are provided.

\section{Hypothesis 2:}

ICT facilities utilization and mathematics teachers' effectiveness in secondary school.

The findings of the above hypothesis showed that there is no significant influence of ICT facilities utilization on the teaching effectiveness of mathematics teachers in public secondary schools in Cross River State. The null hypothesis was retained and the alternate rejected. The finding from hypothesis five (5) is consistent with that of Asiabaka (2002) who also agreed that ICT facilities used in secondary schools are mostly in the areas of planning and administration and not in teaching and learning of mathematics. The utilization of computer information technology facilities in the teaching of mathematics according to Asiabaka should be seen as new innovation in secondary schools.

Additionally, the result have significant bearing with the position of Kaku (2005), who observed that the problem of ICT- facilities availability, accessibility, acquisition, teachers' attitude as well as other teacher characteristics collectively inhibit the effective utilization of ICT facilities for pedagogical purposes. That ICT facilities utilization cannot distinctly influence mathematics teachers' effectiveness in but a combination of multiple factors. The author opined that most secondary schools have only one computer attached to the internet for a large population of both teachers and students to use. Effectiveness on the part of the teacher cannot be guaranteed in this regards.

Conversely however, the finding of the above hypothesis departs from the views of Eraut, 1995; Dawes, et al (2003), who affirmed that effective utilization of ICT facilities by teachers can greatly enhance and influence teachers' effectiveness in the classrooms and manifest itself in the overall development of students thinking capacity and understanding across the curriculum span.ICT facilities utilization in mathematics teaching is critical, but given the findings of this study, the researcher believes that there can be no teaching effectiveness in the midst of unskilled labour force that lacks the technical capabilities and skills to effectively utilized and deploy modern facilities for pedagogical purposes, especially in the teaching and learning of mathematics in our secondary schools. The result of this hypothesis affirms that the utilization of ICT facilities by mathematics teachers cannot guarantee their teaching effectiveness.

The researcher also feels that ICT facilities utilization by teachers can influence their teaching effectiveness in mathematics only when certain actions are taken such as; installation and equipping of computer laboratories with functional computers with the mathematics software, training the teachers with the right application using seminars and workshops as platforms 


\section{CONCLUSION}

Based on the findings of study, it was concluded that both teachers' attitude towards ICT facilities and ICT facilities utilization cannot significantly influence teachers' teaching effectiveness in mathematics. It was found that other teacher and pedagogical -related as well as environmental variables such as basic knowledge of the subject matter, interest, in-service training and motivation as well as competency have vital roles to play in the determination of mathematics teacher effectiveness in the classrooms in our public secondary schools.

\section{RECOMMENDATIONS}

From the findings obtained from the analysis of data and testing of hypotheses in the study, the researcher would make the following recommendations:

1. Relevant authorities should make adequate and regular sensitization to create and sustain a new or positive attitude among teachers towards ICT facilities. There is an assurance that mathematics teachers in our secondary schools are ready to embrace ICT integration in their teaching.

2. The needed training on the use of these facilities should be provided to mathematics teachers to put them in a better position for an effective mathematics teaching in our public secondary schools in Cross River State. Provision of electricity should be given priority as almost all ICT facilities are electricity-dependent.

3. Government and school authorities should provide, build and equip computer laboratories and studios; furnish them with state of the art ICT facilities to give mathematics teachers and students access to some these ICT facilities. This should be done together with the provision of constant electricity to power the equipment so provided. In-service training programmes on the use of Information and Communication Technology (ICT) facilities should be made available to teachers (mathematics) to equip them with the needed technical knowledge and skills on how to utilize ICT facilities in the classroom. 


\section{REFERENCES}

1. Adonni, E. E. \&Anie, S. O. (2006). An assessment of computer literacy skills of professionals in Nigeria Universities Libraries. Library Hi Tech News.

2. Afe, J. O. (2003). Teacher effectiveness: Imperative for implementing universal basic education in Nigeria. Journal of Nigeria Academy of Education.1(1)1-9

3. Ajayi, G. O. (2008). Challenges to Nigeria globalization and information age. Proceedings of workshop on National Information and Communication Infrastructures. Policy plan and strategies, Abuja, Nigeria, March, 28.

4. Ajayi, G. O. (2008). National Information Technology Development Agency NITDA). Retrieved March, 2014 from. http//www.ejds.orga/meeting /2003/icip/papers/Ajayi.pdf.

5. Akpan, A. A. (1996). Teacher effectiveness as a determinant of students' performance in mathematics: A theoretical review. Journal of Research Information in Education. 1(1) 89-99

6. Akuegwu, B. A., Ntukidem, E. P. Ntukidem, P. J. \&Jaja, G. (2011). Information and Communication Technology facilities utilization for quality instructional services delivery among Universities lecturers in Nigeria. Journal of Higher Education in Africa 3(1): 33-53.

7. Albirini, A. A. (2004). An exploration of the factors associated with the attitude of high school teachers in Syria towards Information and Communication Technology (ICT). Unpublished thesis, The Ohio State University.

8. Apagu, V. V. (2008). Availability and utilization of ICT facility or teaching and learning of Vocational and Technical Education in Yobe State Technical Colleges. American Journal of Engineering Research (AJER) 4(2): 113-115.

9. Asiakaka, I. P. (2010). Access and use of ICT for administrative purposes by principals of government secondary schools in Nigeria. Retrievedfrom:www.sciencepub.net/researcher/researcher/0201/070989/access/pub/research02014350.pdt. Accessed on: $8^{\text {th }}$ July, 2016

10. Condie, R. \& Livingston, K. (2007). Blending online learning with traditional approaches: Changing practice. British Journal of Educational Technology 38(2):337-348.

11. Cuban, L. (1986). Teachers and Machines. The classroom use of technology since 1920. New York: Teacher College Press.

12. Eraut, M. (1995). Group work with computers in British primary schools. Journal of educational computing. 13: $61-87$

13. Evans, E. D. (2006). Transition to teaching. New York. Holt, Rinehart and Winston

14. Hare, H. (2007). Information and Communication Technology (ICT) in education in Tanzania, in G. Farrell, S. Isaac \& M. Trucano (ed). Survey of ICT and Education in Africa: 53 Country Report, C: info Dev/World Bank, Washington

15. Harrison W. \& Rainer, K. (1992). An examination of the factors, structures and concurrent validates for the computer attitude scale, the computer anxiety rating scale and the computer self-efficacy scale. Journal of Educational and Psychological Measurement 52: 735-744

16. Harrison, W. \& Rainer K. (1992). An examination of the factor structures and concurrent validates for the computer attitude scale, the computer anxiety rating scale and the computer self-efficacy scale. Educational and Psychological Measurement. 52: 735-744

17. Kaku, F. A. (2005). The use of Internet by secondary school teachers in the rural areas of Delta State The case of Udu Local Government Area Abraka; Delta State University. Unpublished B.Sc. (LIS) Project.

18. Keith, M. L. (2000). New technology and knowledge acquisition and use in developing countries. A Journal of comparative and International Education 30(3): 313-321

19. Kirkwood, M. (2000). Infusing higher-order thinking and learning to learn into content instruction. A case study of secondary computing studies in Scotland. Journal of curriculum studies. 32(4): $509-535$.

20. McClaim, K. \& Cobb, P. (2001).Supporting students' ability to reason about data. Educational studies in mathematics

21. Messick, D. \& Cook G. (1983). Equity theory: Psychological \& Sociological perspective.Praeger.

22. Mselle, L. J. (2012). The use of ICT in Tanzania: Teaching and learning improvement in Higher Education. Proceedings of a workshop held from $28^{\text {th }}$ March to $3^{\text {rd }}$ April, 2012 at the University of Dodoma, 1: 80-99.

23. Naser, J. A; Leong, L. M. \& Fong, S. F. (2010). Teachers' attitude and levels of technology use in classroom. International Journal education studies 3(2): 211-218.

24. National Centre on Adult Literacy Technical Report, Britain, (2005). Retrieved March, 2014 from: http//www.ejds.organ. Literacy/2003/ icip/papers/ncalt.pdf.

25. Ndibalema, P. (2014). Teachers' attitude towards the use of Information Communication Technology (ICT) as a pedagogical tool in secondary schools in Tanznia: A case study of Kondoda District. International Journal of Education and Research. 2(2):6-10. 
26. Nyarusy, F. (2006). TH effectiveness of ICT application in enhancing teaching and learning processing in private secondary schools in Tanzania. Thesis submitted to University of Dares Salaam in partial fulfilment for the Masters of Arts (Information Studies).

27. Okorie, E. U. \&Ajah, J.J. (2014).Teachers' attitude towards the use of computer software package in teaching Chemical Bonding. International Journal of energy and Environmental Research 2(2): 9-18.

28. Olubiyo, P. O. \&Sheyi, R. M. (2011). Internet exploitation and effective library and information services in Nigeria. Journal of Librarianship in information science in Africa. 2(1): 15 -25.

29. Onyekuru, B. U. \&lbebunam J. O. (2013). Teaching effectiveness in Emohua Local Government Area of River State, Nigeria. European Scientific Journal, 9(28) 212-223.

30. Teo, T. (2008). Assessing the computer attitudes of students: An Asian perspective. Journal of Computers in human behaviour. 2(4): 1634-1642

31. Ugwu, M.I. (2011). Attitude of librarians towards the use of Information and Communication Technology (ICT) in Nigerian Universities. African Library Sentinal. A journal of Library and Information Science. 1(2): 39-44. 